\title{
Instructional Media for Using the Program Autodesk Robot Structural Analysis Professional
}

\author{
Jaturawit Sirimaha*, Natawut Chaiwino \\ Department of civil engineering \\ Rajamangala University of Technology Thanyaburi \\ Pathum Thani, Thailand \\ *jaturawit_s@rmutt.ac.th
}

\begin{abstract}
Nowadays, programs used in construction work are important in drawing and design. Several options are available. Design programs are two- and three-dimensional structural analysis and design programs which can analyze large and complex structures accurately and rapidly. Moreover, a design software can design various types of building structures and constructions. A video media of software tutorial was created to make teaching and learning more efficient and to easily understand how to use the program for accurate calculation, analysis and design by using the Autodesk Robot Structural Analysis Professional program. A steel structure warehouse with a dimension of $30 \times 60$ meters was chosen as an example in this study. The instructional media was produced to demonstrate the use of Robot Structural Analysis Professional software in analysis and design of the selected warehouse step by step. The instructional media was evaluated the effectiveness of the content by five experts. The revised instructional media according to the comments of the experts was tested by 34 students via pretest and posttest. The result was found that analysis for efficiency in production technical is in a very good level. Analysis for content performance is in a good level. Production technical satisfaction analysis is in a good level. The average score of content satisfaction analysis, test results, users, and media usage before studying was 8.176, and after studying was 14.294. The score after studying was statistically significant more than before studying at 0.05 .
\end{abstract}

Keywords—structural analysis, building structures, instructional media

\section{INTRODUCTION}

Currently, the program can be considered as a necessity for everyday work. Several programs are available to be used and each program has its own advantages. If the user does not have sufficient knowledge of the program, it may cause problems and errors.

Autodesk Robot Structural Analysis Professional is a 2D and 3D structural analysis and design program capable of analyzing large and complex structures accurately and quickly $[1,2]$. Able to design various types of building structures and constructions The structural steel structure Reinforced concrete, wood and aluminum as well.
Instructional media is necessary for teaching process [3]. To illustrate and explain the use of the program in each step for the learners to be able to understand more easily and efficiently, the researcher has prepared the video media. The media also gives an example and explain how to use the program step by step for the learners to gain more knowledge and understanding of how to use the Autodesk Robot Structural Analysis Professional program.

\section{EXPERIMENTAL PROGRAM}

The instructional media of warehouse design with the size of 30 x 60 meters was produced using the Autodesk Robot Structural Analysis Professional software as follows [4]:

- Study information and procedures for using Robot Structural Analysis program

- Determine the steps for using the Robot Structural Analysis program, divided into 10 steps as follows:

\section{1) Set project type}

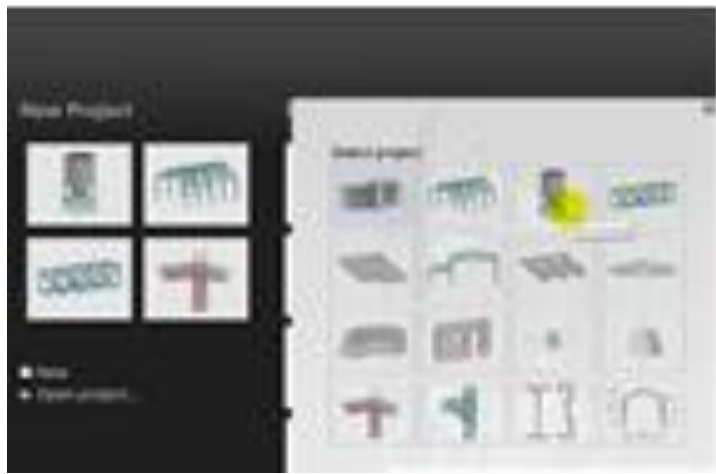

Fig. 1. Set project type. 
2) Various settings in the program

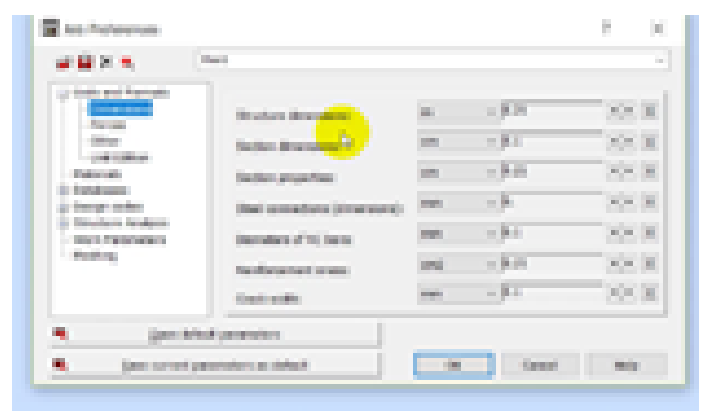

Fig. 2. Program settings.

3) Set axis definition

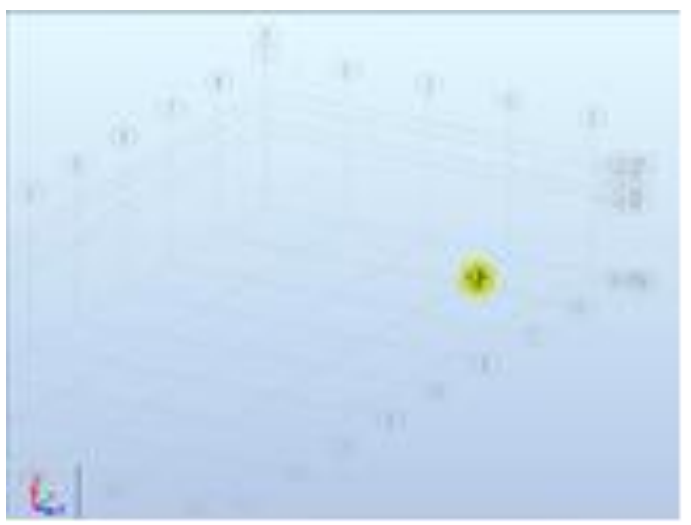

Fig. 3. Axis definition.

4) Define a bar section

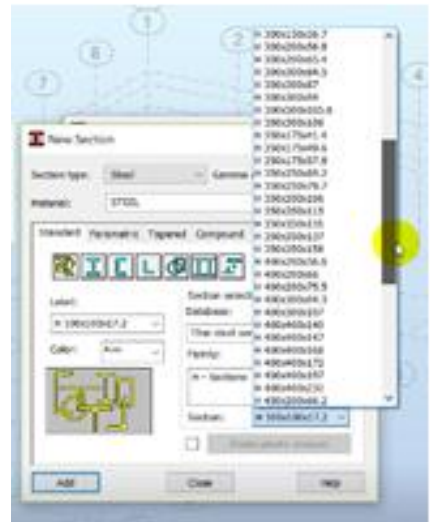

Fig. 4. Define section.

5) Create a $3 D$ model

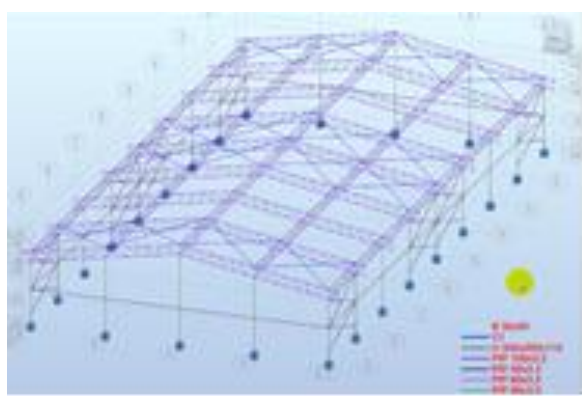

Fig. 5. 3D model.

6) Define supports

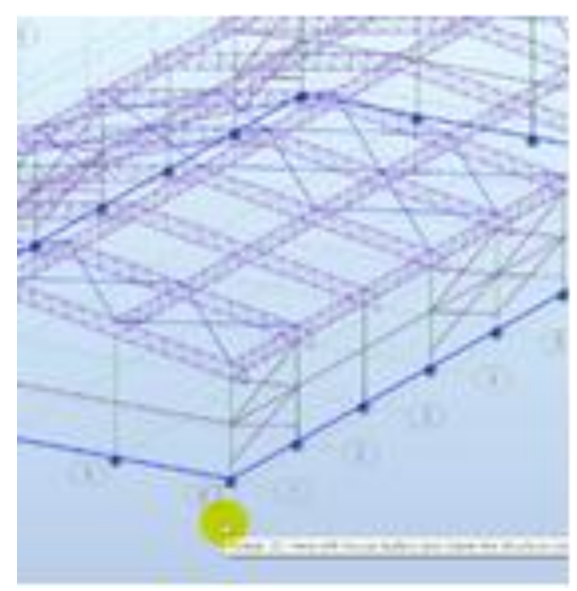

Fig. 6. Supports.

7) Load definition

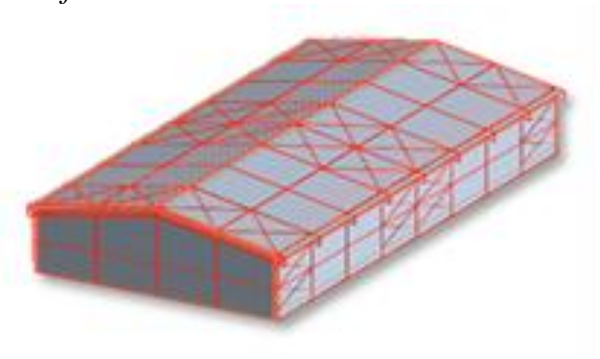

Fig. 7. Load definition.

8) Analysis

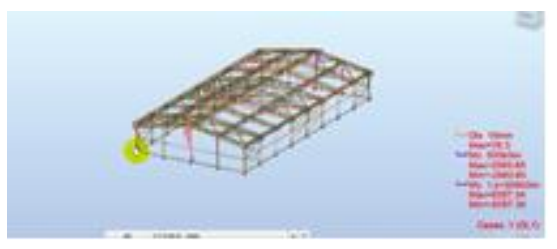

Fig. 8. Analysis. 
9) Design

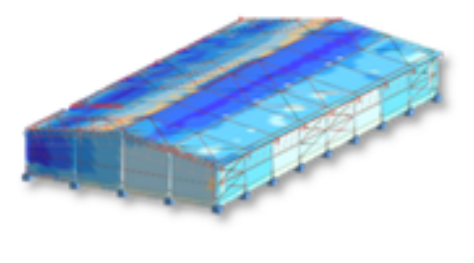

Fig. 9. Design.

\section{0) Design report}

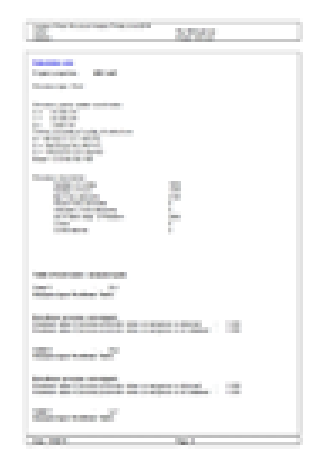

Fig. 10. Report.

- Produce instructional media for using Robot Structural Analysis program in video media.

- Evaluate the effectiveness of the material and technical teaching materials by experts and sample [5].

- Conclusion

\section{TEST RESULTS AND DISCUSSIONS}

Analysis for efficiency in production technique. The criteria for interpreting the mean analyzes of the data shown in Table 1.

TABLE I. INTERPRETATION CRITERIA, MEAN MEAN LEVEL OF OPINION OF VIDEO MEDIA

\begin{tabular}{|l|l|}
\hline \multicolumn{1}{|c|}{ Mean } & \multicolumn{1}{c|}{ Comment level } \\
\hline $4.21-5.00$ & Very good \\
\hline $3.41-4.20$ & good \\
\hline $2.61-3.40$ & moderate \\
\hline $1.81-2.60$ & Fair \\
\hline $1.00-1.80$ & Should improve \\
\hline
\end{tabular}

Evaluation of the Efficiency of Instructional Materials in Production Techniques There are 5 experts evaluating using the evaluation results to find the mean which can be summarized as shown in Table 2 .
TABLE II. Shows The Mean Results Of Analysis OF Production TECHNICAL DATA

\begin{tabular}{|l|l|l|}
\hline \multicolumn{1}{|c|}{ list } & $\overline{\boldsymbol{X}}$ & Satisfaction level \\
\hline Visual technique & 5.00 & Very good level \\
\hline 1. Suitability meets content & 5.00 & Very good level \\
\hline 2. Clarity of illustrations & 5.00 & Very good level \\
\hline 3. Image size in presentation & $\overline{\boldsymbol{X}}$ & Satisfaction level \\
\hline list & 4.50 & good level \\
\hline $\begin{array}{l}\text { 4. The relationship between picture and } \\
\text { sound }\end{array}$ & \multicolumn{3}{|l|}{} \\
\hline Sound technique & 4.50 & good level \\
\hline 5.Sound technique & 4.00 & good level \\
\hline 6. Clarity, sound accuracy & 4.00 & good level \\
\hline 7. Rhythm for reading aloud & 4.50 & good level \\
\hline $\begin{array}{l}\text { 8. Language or words that are easy to } \\
\text { understand }\end{array}$ & 5.00 & Very good level \\
\hline 9. Proper reading patterns & 5.00 & Very good level \\
\hline Alphabet technique & 5.00 & Very good level \\
\hline 10. Scale and read clarity & \\
\hline 11.Highlighting messages and key points & \multicolumn{2}{|l}{} \\
\hline
\end{tabular}

Evaluation of the effectiveness of teaching materials for content. There are five experts evaluating using the evaluation results to find the mean, which can be summarized as in Table 3.

TABLE III. ShOWs The MEAN RESUlts OF ANALYSIS OF CONTENT DATA

\begin{tabular}{|l|c|l|}
\hline \multicolumn{1}{|c|}{ list } & \multicolumn{1}{|c|}{$\overline{\boldsymbol{X}}$} & \multicolumn{1}{c|}{ Satisfaction level } \\
\hline 1. Accuracy of content & 5.00 & Very good level \\
\hline 2. Content integrity & 4.00 & good level \\
\hline 3. Content resolution & 4.00 & good level \\
\hline 4. Correct order of procedures & 4.00 & good level \\
\hline $\begin{array}{l}\text { 5. Explanation of operating } \\
\text { procedures is clear. }\end{array}$ & 5.00 & Very good level \\
\hline
\end{tabular}

Evaluation of satisfaction of instructional media on production techniques a sample of 31 people evaluated by using the evaluation results to find the mean which can be summarized as in Table 4.

TABle IV. Shows The Mean Results Of The Production TECHNICAL SATISFACTION ANALYSIS

\begin{tabular}{|c|c|c|}
\hline list & $\overline{\boldsymbol{X}}$ & $\begin{array}{c}\text { Satisfaction } \\
\text { level }\end{array}$ \\
\hline \multicolumn{3}{|l|}{ Visual technique } \\
\hline 1. Suitability meets content & 4.30 & good level \\
\hline list & $\bar{X}$ & $\begin{array}{l}\text { Satisfaction } \\
\text { level }\end{array}$ \\
\hline 2. Clarity of illustrations & 4.40 & good level \\
\hline 3. Image size in presentation & 4.60 & Very good level \\
\hline $\begin{array}{l}\text { 4. The relationship between picture and } \\
\text { sound }\end{array}$ & 4.40 & good level \\
\hline \multicolumn{3}{|l|}{ Sound technique } \\
\hline 5.Sound technique & 4.00 & good level \\
\hline 6. Clarity, sound accuracy & 4.20 & good level \\
\hline 7. Rhythm for reading aloud & 4.40 & good level \\
\hline $\begin{array}{l}\text { 8. Language or words that are easy to } \\
\text { understand }\end{array}$ & 4.60 & Very good level \\
\hline 5.Sound technique & 4.30 & good level \\
\hline \multicolumn{3}{|l|}{ Alphabet technique } \\
\hline 10. Scale and read clarity & 4.40 & good level \\
\hline 11.Highlighting messages and key points & 4.40 & good level \\
\hline
\end{tabular}


Assessing the satisfaction of the instructional media content a sample of 31 people evaluated by using the evaluation results to find the mean which can be summarized as in Table 5 .

TABLE V. ShOWS The MEAN Results OF CONTENT SATISFACTION ANALYSIS

\begin{tabular}{|l|l|l|}
\hline \multicolumn{1}{|c|}{ list } & $\overline{\boldsymbol{X}}$ & \multicolumn{1}{c|}{ Satisfaction level } \\
\hline 1. Accuracy of content & 4.50 & good level \\
\hline 2. Content integrity & 4.60 & Very good level \\
\hline 3. Content resolution & 4.30 & good level \\
\hline 4. Correct order of procedures & 4.20 & good level \\
\hline $\begin{array}{l}\text { 5. Explanation of operating } \\
\text { procedures is clear. }\end{array}$ & 4.50 & good level \\
\hline
\end{tabular}

Sample test the results of the pre- and post-training test were used to find the mean values by experimenting with 34 students was tested by taking 20 multiple-choice tests as shown in Table 6.

TABLE VI.

Shows The Mean SAMPle Test Results

\begin{tabular}{|l|l|l|l|l|l|}
\hline & \multicolumn{1}{|c|}{ n } & \multicolumn{1}{|c|}{ mean } & S.D & t & Sig. \\
\hline Pre test & 34 & 8.176 & 2.066 & & \\
\cline { 1 - 3 } Post test & 34 & 14.294 & 3.186 & 16.538 & 0.00 \\
\hline
\end{tabular}

It was found that There was a statistically significant difference $(\mathrm{t}=-16.538, \mathrm{p}=0.00)$.

\section{RECOMMENDATION}

The study other structures authors would like to propose the preparation of teaching materials for concrete structural design. To guide further study of the use of the Autodesk Robot Structural Analysis Professional program.

\section{REFERENCES}

[1] P Brahm, Robot Structural Analysis 1st edition Bangkok Diseno co.,ltd., 2020.

[2] S. Chaicharoen "(Media)." [Online]. Accessible from: https://www.classstart.org/classes/297?fbclid=IwAR12QOxNTDbImb1x GJIDSCKdQZqo2n6Mxg84jXaZToLfYB5HG9ViyEqqyjg (Date of retrieval: 12 January 2020)

[3] Gerlach and Ely, "Teac instructional media" [Online].Accessible from http://plam1806.blogspot.com/2014/12/blog-post_15.html (Date of retrieval: 12 January 2020)

[4] S. Thueksathit, Development of an Individual Teaching Kit on Computer System Structure on Hardware Computer System Structure. For diploma students Professional Advanced Year 1 in Business Computing Rayong Technical College Rayong Province. Bachelor of Education.Thesis in Educational Technology and Communication Sukhothai Thammathirat Open University, 2014.

[5] K. Prakanree, Development of an individual teaching kit on the management of methane in the charcoal layer. A stone for commissioned officers, Department of Military Energy, Ministry of Defense. Doctor of Education degree thesis Department of Adult Education Srinakharinwirot University, 2008. 